\begin{tabular}{llllllll}
$\mathbf{A}$ & $\mathbf{R}$ & $\mathbf{T}$ & $\mathbf{Y}$ & $\mathbf{K}$ & $\mathbf{U}$ & $\mathbf{L}$ & $\mathbf{Y}$ \\
\hline
\end{tabular}

ROCZNIKI TEOLOGICZNE

Tom LXVII, zeszyt 3 - 2020

DOI: https://doi.org/10.18290/rt.20673-1

REV. MARTIN MICALLEF

\title{
THE USE OF ZETEO IN THE FOURTH GOSPEL: A DEBATE WITH JOHN PAINTER'S THE QUEST FOR THE MESSIAH
}

\begin{abstract}
This article will tune into a debate with John Painter's, The Quest for the Messiah: The History, Literature and Theology of the Johannine Community, as a monograph that deals extensively with the theme of zeteo - seeking - in the Gospel of John. In this monograph, Painter has led to certain valuable results in his efforts to establish the importance of zeteo in this Gospel by studying its quest and rejection stories. The article will reveal the degree on which Painter has understood the historical origin of zeteo against the Sitz im Leben of the Johannine Community. This exercise will sketch out some of the main lines of development in Painter's work and highlights certain directions of recent research on the Gospel of John.
\end{abstract}

Key words: Seeking; historical critical method; sources; Johannine Community; quest; rejection.

In spite of its many differences from the Synoptic Gospels, John's Gospel $^{1}$ purports to tell the story of Jesus, whose status as the Messiah, the Son of God, and revealer of the Father, constitutes the first major theme. The relationship between Jesus as the Son of God, and the Father, serves as a model for the believer's relationship with Jesus, and through him, with God. This relationship is expressed in Johannine terms, such as, "to abide," (menein), which is a consequence of one's seeking. Those who "seek" (zeteo)

Rev. Dr Martin Micallef, Department of Sacred Scripture, Hebrew and Greek, Faculty of Theology, University of Malta; address for correspondence: Msida MSD 2080, Malta; e-mail: martin.f.micallef@um.edu.mt

${ }^{1}$ By "John," "the Gospel of John," "John" or "the Fourth Evangelist," and so, we simply mean the Fourth Gospel without making any claim on the authorship of this Gospel. 
Jesus for the right reasons, will be able to find him, and to remain/abide with him. These terms form part of the Fourth Gospel's distinctive narrative technique, in a way that they are given new theological connotations to achieve effects that cause surprise. Zeteo seems to be one of these words which has been scrutinized by John Painter's work, The Quest for the Messiah: The History, Literature and Theology of the Johannine Community, first published in 1991. ${ }^{2}$ The sub-title of Quest makes it clear that Painter considers the sociological setting of the Johannine community a very important factor that shaped its theology. From the outset of Quest, Painter defends the hypothetical nature of the historical reconstruction of this community and forcefully argues that if we understand some of the concerns and struggles the Johannine community faced, we are in a better position to understand and appreciate the Gospel's intentions.

In this article we intend to tune a debate with Painter's Quest to examine whether his insights can deepen our understanding of the use of zeteo in the Fourth Gospel. The aim of this exercise is not only to sketch out some of the main lines of development in Painter's work, but also to highlight certain directions of recent research on the Fourth Gospel which can add weight to the main body of exegesis.

\section{A WORKING HYPOTHESIS}

Painter has spent great efforts to establish the importance of zeteo in the Fourth Gospel by studying its quest and rejection stories. At the outset of his study, Painter presents the threefold objectives of Quest. First, the recognition of "the evidence that suggests a process of composition" ${ }^{3}$ behind the Fourth Gospel. Painter acknowledges the difficulty to detect the underlying tradition and states he will not "attempt to isolate and reconstruct the source(s) in detail." "The first task of Quest is intimately related to the second task, namely, that "of recognizing the evidence that suggest that the Gospel was shaped in the history of the Johannine believers." Painter endeavours to demonstrate how the "impact of that history has left its mark in the Gospel

${ }^{2}$ John PAINTER, The Quest for the Messiah: The History, Literature and Theology of the Johannine Community, ed. 2 (Edinburgh: T\&T Clark, 1993).

3 Ibid., 28.

${ }^{4}$ Ibid.

${ }^{5}$ Ibid. 
and the developing Gospel can be seen as a response to a series of crises."6 Outlining the development of the tradition which constitutes the first task, and identifying the historical situation behind this tradition which is the second task leads to the third task, namely, that of interpreting the Fourth Gospel in its complete form. ${ }^{7}$

Painter follows C.K. Barrett, ${ }^{8}$ whose suggestions on the socio-historical setting from which the Fourth Gospel emerges foreshadow Raymond E. Brown's massive commentary on the Fourth Gospel "which gave expression to the hypothesis of the development of the Gospel in a number of stages over a lengthy period of time."9 In dialogue with these works, Painter acknowledges that those responsible for the Fourth Gospel have written their history in the guise of a narrative about the ministry of Jesus Christ. Behind the einmalig (events reported) level of the Fourth Gospel there are the contemporary events experienced by the Fourth Evangelist and his community. In 1820, K.G. Bretschneider had already stated that the Fourth Gospel "is more an apologia than a work of history, and its author assumed the role of a polemicist rather than of a historian." Almost a century and a half later, J. Louis Martyn's History and Theology in the Fourth Gospel, ${ }^{11}$ which Barrett considers as "the best attempt to provide a specific Sitz im Leben for the

${ }^{6}$ Ibid.

${ }^{7}$ Because Quest's chapters follow the sequence of the Fourth Gospel, Painter regards his work as one that "can be consulted as a commentary" though not an exhaustive one, since it is written "from the perspective of the quest of the Messiah." Ibid. Judith M. LIEU, "The Quest for the Messiah," Expository Times 103(1992): 345, welcomes Painter's work "for its contribution to the literary analysis and to the integrated study of the Gospel."

${ }^{8}$ C.K. BARRETT, The Gospel according to St. John: An Introduction with Commentary and Notes on the Greek Text, ed. 2 (London: SPCK 1978).

${ }^{9}$ J. PAInTER, The Quest for the Messiah, 2. See Raymond E. BROWn, The Gospel according to John. Anchor Bible 29, 29A (Garden City/New York: Doubleday, 1966-1970). See also Raymond E. BRown, The Community of the Beloved Disciple: The Life, Loves and Hates of an Individual Church in New Testament Times (New York/London: Paulist, 1979).

${ }^{10}$ K.G. BRETSCHNIEDER, Probabilia de evangelii et epistularum Joannis, apostoli, indole et origine (Leipzig, 1820), quoted by John AsHTON, Understanding the Fourth Gospel (Oxford: Clarendon Press, 1993), 10.

${ }^{11}$ J. Louis MARTYN, History and Theology in the Fourth Gospel, ed. 2 (Nashville: Abingdon Press, 1979), first published in 1968. Martyn followed this seminal work by his "Glimpses into the History of the Johannine Community," in The Gospel of John in Christian History: Essays for Interpreters (New York: Paulist, 1978), 90-121; J. Louis MARTYN, "Source Criticism and Religionsgeschichte in the Fourth Gospel," in The Interpretation of John, ed. John Ashton, ed. 2 (Edinburgh: T\&T Clark, 1997), 121-146. 
Gospel,"12 suggests that the Fourth Gospel is a two-level drama. Martyn likens the Fourth Gospel to an archaeological "tell" and considers it as a source which provides some information on the social history of the Johannine Community. ${ }^{13}$ The central premise of Martyn's work raises some vital questions, and thus it merits summarizing. In return this will help us to understand Painter's main arguments on the quest stories in the Fourth Gospel.

\section{A MARK ON THE JOHANNINE TRADITION}

We may compare Martyn's reconstruction of the Johannine Community to a three-act drama: the early period, the middle period, and the later period. According to Martyn, the early period in the history of the Johannine Community involved the conception of a messianic group within the community of the synagogue. Martyn describes this period as a harmonious one that lasted for decades (ca. 46-85 CE). ${ }^{14}$ It involved the low-key message about Jesus as the Messiah on traditional Jewish expectations, that could not be offensive to "the Jews," otherwise the Johannine group could not have formed part and lived within the synagogue. ${ }^{15}$

This peaceful period did not last. There came a second stage in which, according to Martyn, the messianic group became involved in a polemic with others in the synagogue. The title "Christ" formed the real issue in this debate as here would have been a gradual refinement of the Messianic terminology in a way that can no longer be expressed in the traditional messianic categories and far exceeds them in content. Jesus is the Messiah/the Christ, but the Christ who is the "Son of God"; the one who came from God to make God known. ${ }^{16}$ In other words, the term Messiah/the Christ gained a divine status, a content that "the Jews" found intolerable, offensive and blasphemous. According to Martyn's reconstruction, the polemic of the Johannine Community with the synagogue's officials regarding the title "Christ" led to two traumatic actions: excommunication from the synagogue and martyrdom.

${ }^{12}$ C.K. BARRETT, The Gospel according to St. John, 93, no. 1.

${ }^{13}$ See J.L. MARTYN, The Gospel of John in Christian History: Essays for Interpreters, 90-91.

14 Ibid., 92.

15 On this point see J. Ashton, Understanding the Gospel of John, 169.

${ }^{16}$ See Jn 11:27 and 20:31. 
Martyn builds up this argument on three Johannine texts, namely, Jn 9:22; $12: 42 ; 16: 2$ and strongly argues that the language concerning the expulsion from the synagogue mentioned in these texts is anachronistic and does not reflect a situation in Jesus' time. The texts are a clue that assists the reader in locating the Johannine Community as one that has been recently expulsed from the synagogue. ${ }^{17}$ Martyn finds an exact historical occasion for this situation, namely, the Birkat ha-minim or the Benediction against Heretics. According to Martyn, the Eighteen Benedictions recited in the synagogues were reformulated precisely during this time, roughly between 85-90 CE by the Council of Jewish Rabbis at Jamnia under the leadership of Rabbi Gamaliel II. They introduced a public cursing of the "heretics" (the minim) and the "Nazarenes" whom Martyn identifies as the Jewish Christians. ${ }^{18}$

In view of this trauma, Martyn describes the later period in the history of the Johannine Community as a time in which its members now became a separated community of Jewish Christians. ${ }^{19}$ According to Martyn, the concern of this community now was not so much with those who had not believed in Jesus, as with those who had believed but had hidden their belief in Jesus as the Messiah, the Son of God and remained part of the synagogue.

Taking the lead from Martyn, Painter considers the story of the healing of the man born blind in Jn 9:1-41 as an important clue of how the story of Jesus as narrated in the Fourth Gospel reflects the history of the Johannine Community. On the one hand, the story reads somewhat like many other stories of Jesus' miracles. On the other hand, in reading this story one feels that something else is going on. Painter argues that Jn 9:22 reveals the split between the Johannine Community and the synagogue. For Painter, the polemical situation is almost certainly the most significant single factor that left its mark on shaping the Johannine tradition. ${ }^{20}$ For Painter, the task of reconstructing the history of the Johannine Community, therefore, is not "optional" but "essential." ${ }^{21}$ Painter's intention, however, was not to reconstruct the hi-

17 J.L. MARTYN, History and Theology in the Fourth Gospel, 37 reconstructs the miracle story in Jn 9 "presented as a formal drama, and allowed to mount its actors, so to speak, on a two-level stage so that each is actually a pair of actors playing two parts simultaneously [...]. At least in part, it seems to reflect experiences in the dramatic interaction between the synagogue and the Johannine church. To observe these reflections one needs only to be aware of the two-level stage."

18 See J.L. MARTYN, The Gospel of John in Christian History, 103-105.

19 See ibid., 106-107.

20 See J. PAINTER, The Quest for the Messiah, 61.

21 Ibid., 4. 
story of the Johannine Community for its own sake. He contends that Quest's findings regarding the Johannine Community's history promises "to throw light on our interpretation of John," 22 particularly on the theme of the quest of the Messiah.

\section{THE QUEST STORIES}

Following Brown's sophisticated literary theory, Painter presents a model for understanding the composition of the Fourth Gospel. There is "the tradition used by the evangelist" followed by "the shaping of this in three consecutive editions," and "a final redaction prior to publication." 23 The importance of Painter's working hypothesis for the use of zeteo in the Fourth Gospel is that according to him, the quest stories form part of this tradition used by the Fourth Evangelist. Painter strongly supports the view that the Fourth Evangelist himself "was responsible for the development of many of the traditions into quest stories." 24 According to Painter, the Fourth Evangelist has reformulated these stories with remarkable freedom through the various stages of the Gospel's composition which correspond to the different historical situations of the Johannine Community.

The first quest stories which Painter identify are those found in what he considers as a unified section, namely, Jn 1:19 to 4:54. For Painter, these are not simply stories that reflect the historical circumstances of Jesus and his audience. Painter is rather convinced that the Fourth Evangelist has transformed these traditional stories into quest stories. "The evangelist had developed quest stories from traditional material and has structured 1:19-4:54 on the theme of quest." 25 Painter accounts for this position by recognizing the probability that the Fourth Evangelist has used Synoptic-like inquiry stories to form his own quest stories. $^{26}$

${ }^{22}$ Ibid., 68.

${ }^{23}$ Painter states that "very likely the editions represent a process of ongoing revision but one in which certain watershed can be perceived in the way the tradition has been shaped." Ibid., 66. See also, R.E. Brown, The Community of the Beloved Disciple, 22-24.

${ }^{24}$ J. PAInTER, The Quest for the Messiah, 212.

25 Ibid., 178. See also 212.

${ }^{26}$ Such is the case in the questioning of John the Baptist in Jn 1:19-25. Here Painter claims to have found elements of traditions in particular, traditions that are found in Lk 3:1015. According to Painter, this traditional material, such as the quotation of Isa 40:3 found in both Jn 1:23 and Lk 3:4; the Baptist's witness to the coming one in Jn 1:26-27.33 and Lk 
Painter claims to have found units of early tradition in these episodes. He attests that these traditional miracle stories belong to the first edition of the Gospel, corresponding to an early period in the life of the Johannine Christians. During this period, which according to Painter is characterized by an open dialogue with the synagogue, miracle stories are presented as basis for belief in Jesus as the Messiah. Thus, for example, in examining the miracle story of the feeding of the multitude, Painter acknowledges the importance of recognizing the tradition behind this miracle "as an important beginning in the attempt to understand $\mathrm{Jn} 6 .{ }^{27} \mathrm{He}$ then suggests that the traditional quest story of Jn 6:1-35 belongs to the first edition of the Gospel where it was placed immediately after chapter $4 .^{28}$ The reason for this is the juxtaposition of both stories by the crowd's quest for bread in Jn 6:34 and the Samaritan's quest for water in Jn 4:15. The similarities between these two requests led Painter to conclude that Jn 4 and Jn 6 originally belonged together.

Painter draws similar conclusions in his study of Jn 9 stating that even here the Fourth Evangelist made use of a traditional miracle story that originally formed "part of the a miracle tradition which surfaces again at 2:1-10; 4:46-54; 5:1-9a; $6: 1-21 ; 11 . "{ }^{29}$ Like the story of the royal official's request for the healing of his son in Jn 4:46-54, the miracle of the man born blind in Jn 9:1-41, may also have been built upon a request of healing, thus making the story a miracle quest story. Painter entertains the idea that these traditional miracles stories, forming part of the first edition of the Gospel, were used in the synagogue as an attempt to win over its members to faith in Jesus as the Messiah. Jesus was presented in line with what we read in the Acts 2:22, namely, as "a man attested to you by God with mighty works and wonders and signs." 30 On the other hand, Painter shares the opinion of many other Johannine scholars, that the Fourth Evangelist seems critical of

$3: 16$; the descent of the Spirit followed by the declaration of the voice from heaven in Jn 1:3234 and Lk 3:22; and the call of the disciples in $\mathrm{Jn}$ 1:35-51 and Lk 5:1-11.27-32 "have been taken up in distinctive Johannine fashion.” Ibid., 167.

${ }^{27}$ Ibid., 253.

${ }^{28}$ See Ibid., 267-276.

${ }^{29}$ Ibid., 310.

${ }^{30}$ Ibid., 311. For Painter, this kind of "faith based on signs was a real beginning, even if only a beginning." Ibid., 312 . 
faith based on signs. ${ }^{31}$ Painter maintains that this negative attitude reflects a later stage in the history of the Johannine Community when it was in conflict with the synagogue. Thus, in his concluding comments on the traditional quest story that narrates the healing of the official's son in Jn 4:46-54, Painter once more draws attention to this fact, saying:

Although critical of the demand for signs the miracle quest story was used apologetically to appeal to those within the synagogue who were open to the messianic claims of Jesus. The evangelist's strategy was to narrate and interpret a selection of signs with a view to leading the readers to authentic faith in Jesus, a true understanding of his messiahship (20:30-31). ${ }^{32}$

Painter's most important argument for the study of these quest stories is that the Fourth Evangelist has reworked his tradition into quest stories. The above presentation serves as an example of how Painter deals in detail with this conclusion and sets it as a major clue to his theory of composition.

\section{THE REJECTION STORIES}

Painter's theory of composition does not limit itself to quest stories, but also draws on the rejection stories in the Fourth Gospel. From the very beginning of Quest, Painter writes that these rejection stories:

Were developed by making use of the tradition which portrayed Jesus' conflict with Jewish authorities which led to his arrest, trial and execution. In John, however, the tradition portraying Jesus' conflict with Jewish authorities is used in a way that takes account of the conflict experienced by the Johannine community, culminating in their expulsion from the synagogue. ${ }^{33}$

Painter probes some of the other narrative dynamics starting with what he calls "the paradigm of rejection" in Jn $5 .{ }^{34}$ Here, Painter underpins the following argument:

${ }^{31}$ See for example, Rudolf Bultmann, The Gospel of John, trans. G.R. Beasley-Murray (Oxford: Blackwell, 1971), 131.

32 J. PAINTER, The Quest for the Messiah, 210.

${ }^{33}$ Ibid., 7.

${ }^{34}$ On this point see the overview on Quest by Dietmar NEUfELD, "The Quest for the Messiah," Catholic Biblical Quarterly 57(1995): 604-605. 
Rejection stories have also been build upon the basis of some quest stories in such a way that the theme of rejection has come to dominate them. What this suggests is that rejection stories belong to a later situation when the Johannine Christians had been excluded from the synagogue. At this stage John came to argue that the quest for the Messiah could only be fulfilled when Jesus had been rejected. ${ }^{35}$

Thus, when Painter comes to comment on the episode of the healing of the man who has been ill for thirty-eight years, he claims that Jn 5:1-9 constitute a traditional story unshackled by conflict motifs. The rejection of Jesus is introduced without much ado by a short note in v.9c: "Now the day was a Sabbath," and intensifies as Jesus justifies his action on the basis of his relation to the Father in v.17. Painter attempts to show that the note of rejection has been inserted within this traditional miracle story. ${ }^{36} \mathrm{He}$ firmly acknowledges "that the evangelist was responsible for reworking a miracle story into a rejection story and did so by the addition of the subsequent dialogues." 37 The reason for this, Painter claims, is not to persuade those who have rejected Jesus to accept him. Instead, the reworking of this story as a rejection story reflects the charge of ditheism brought by "the Jews" against the Johannine believers. ${ }^{38}$

The miracle story which once was used to demonstrate Jesus' sovereign knowledge, control, and power, in an attempt to win other Jews to faith in Jesus, came to be used in the conflict with the synagogue. Then the Mosaic Law, especially Sabbath Law, was the principal focus. The dialogues evidence the use of the miracle story in that controversial context in which the synagogue demanded the choice between Jesus or Moses. Initially the evangelist responded that no choice was necessary because acceptance of Moses' words leads to belief in Jesus, 5.39-40, 45-47. Such a position antedates the exclusion of believers in Jesus from the synagogue. ${ }^{39}$

Taking Jn 5 as a starting point, Painter regards the Fourth Gospel's rejection stories as belonging to a later situation in the life of the Johannine Christians, when these had been excluded from the synagogue. ${ }^{40}$ In Painter's

\footnotetext{
35 J. PAINTER, The Quest for the Messiah, 214.

36 See ibid., 312-316. Painter takes a similar position when he comments on Jn 9:14.

37 Ibid., 216.

38 See ibid.

39 Ibid., 222.

40 See ibid., 214.
} 
own words: "the way the rejection stories have come to dominate the Gospel from chapter 5 onwards suggests that a Gospel that once appealed more openly to Jews of the synagogue has been modified to take account of a synagogue reaction." ${ }^{41}$ The importance of such a conclusion is apparent in Painter's interpretation of Jn 6. Here he claims to have compiled evidence suggesting how "a series of editions expanded the Gospel in various ways." 42 In fact, Painter regards Jn 6:1-35 as a traditional story that originally formed part of the first edition of the Gospel. In a further exploration, he says that it is not difficult to recognize that this quest story "has become predominantly concerned with rejection." "43 Focusing upon v.36 - "You have seen and yet do not believe" - Painter highlights that the Jewish unbelief "comes as a shocking announcement." 44

According to Painter, this negative pronouncement which introduces the note of rejection did not form part of the first edition. Then, he strongly argues that verses 36-40 were inserted later on to provide a transitional addition to verses 41-59. Taken together, these verses form a negative conclusion to the original quest story that the Fourth Evangelist himself transformed into a rejection story in the second edition of the Gospel. ${ }^{45}$ As a result, Jn 6 gained a new position in the narrative sequence. It no longer follows Jn 4 immediately. Instead, the Fourth Evangelist has placed Jn 6 within the rejection section of the second edition of the Gospel simply because chapter 5 sets the pattern for the response of Jewish rejection. Although Painter is not blind to the problems that such a shift creates in the itinerary of Jesus' ministry, ${ }^{46}$ he also underscores that the note of rejection in Jn 6, which according to his reconstruction had led to the translocation of this chapter in the second edition of the Gospel, reflects a situation marked by the expulsion of the Johannine Christians from the synagogue. ${ }^{47}$

Painter seriously takes this way of reading the Fourth Gospel as he goes on to reflect in some detail on Jn 10. In this chapter, Painter examines its relationship to the rest of the Gospel, its internal order, the way one should work out the traditions behind the "Amen" and I "am" sayings, and suggests that the

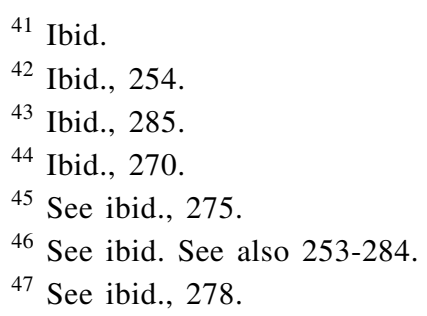


presentation of Jesus as "the good Shepherd" in Jn 10 reflects a context of conflict which led to two different interpretations. The first interpretation covers verses 7-10 in which Jesus is no longer seen as "the Shepherd," as one would expect after reading verses 1-5. Instead, Jesus becomes "the door" who stands in contrast to the "thieves" and "robbers" that Painter identifies as the Jewish leaders who have rejected Jesus and the Johannine community. ${ }^{48}$ Verses 11-18 constitute the second interpretation. Here the "hiring" and the "wolf" replace the "thieves" and the "robbers." In this replacement, Painter no longer perceives a conflict between the Johannine Christians and the Jewish synagogue. Instead, this change in terminology points to an internal conflict among the Johannine Christians. False teaching coming from several of the leaders of this community let to a schism as reflected in $1 \mathrm{John}^{49}$

If Painter claims to have found enough evidence in Jn 5, 6, 9 and 10 for the reconstruction of his theory of composition, he has not been so successful in his examination of Jn 7 and 8. In the course of these two chapters, he admits that he met with the difficulty "to isolate the underlying tradition or to plot something like the course of the evangelist's development of the material." ${ }^{50}$ The difficulty lies in that the dialogues of these chapters are not anchored in miracle stories. Moreover, despite his claim that Quest can be considered as a commentary of the Fourth Gospel, ${ }^{51}$ his study does not delve into these episodes deeply enough. One would also expect something more from Painter's analysis of Jn 11-12. In fact, Painter briefly examines the difficulties found in the story of the raising of Lazarus in Jn 11 and draws similar conclusions he arrived to in his analysis of Jn 6. He holds that Jn 11 is a quest story that the Fourth Evangelist has subsequently over-laid by the theme of rejection. ${ }^{52}$ Painter then treats the episode of the anointing at Bethany narrated in Jn 12:1-8 in just one paragraph. ${ }^{53}$

The same treatment is given to the quest of the crowd in $\mathrm{Jn} 11: 55-56^{54}$ in which Painter incorporates Jesus' triumphal entry into Jerusalem as narrated in Jn 12:12. Surprisingly, Painter does not ascribe any special significance to this quest story as one would expect in a work considered by its author

\footnotetext{
${ }^{48}$ See ibid., 373. See also 352.

${ }^{49}$ See ibid. See also 352-357.

${ }^{50}$ Ibid., 287.

${ }^{51}$ See ibid., 29.

${ }^{52}$ See ibid., 367-374.

${ }^{53}$ See ibid., 375.

${ }^{54}$ See ibid., 376.
} 
as a Commentary. Likewise, Painter's treatment regarding the quest of the Greeks in Jn 12:20-36a is very thin, ${ }^{55}$ and this is exacerbated by the quick glance to Jn $12: 36 \mathrm{~b}-43 .{ }^{56}$ Surely, all this must be considered as one of the most serious shortcomings of Quest. ${ }^{57}$ Painter's handling of these episodes is rather superficial. From Jn 12 Painter jumps to the quest of Jesus' arrest as narrated in $\mathrm{Jn} 18: 1-11,{ }^{58}$ and the quest for Jesus' body in Jn 20:1-18. ${ }^{59}$ Once again, the scant attention given to these important quest stories leaves one feeling a little shortchanged.

On the other hand, Painter's analysis of the Farewell Discourse is more ambitious than that of Jn 9-12. He claims to have found evidence that would show how the Fourth Evangelist composed three consecutive versions of the Farewell Discourse, each version reflects a particular situation of crisis in the history of the Johannine Christians. Painter reaches this conclusion observing that the first version of the Farewell Discourse, that is, Jn 13:31-14:31 was written in a time before the breach of the Johannine Community from the synagogue. In these verses, Painter does not observe any indication of a critical situation with the synagogue. The only crisis he senses is that of abandonment by Jesus. Painter then turns his attention to the second edition of the Farewell Discourse, Jn 15:1-16:4a. Here, he reads a situation that reflects the bitter conflict with the synagogue that eventually led to the casting out of the Johannine Christians from the synagogue. Painter neatly sums up the third edition of the Farewell Discourse, namely Jn 16:4b-33 and proposes a situation where the separation from the synagogue lies in the past. Keeping this in mind, he also reckons Jn 17 as a later addition by the Fourth Evangelist, though he states that this addition should not be considered as another version of the discourse.

55 See ibid., 376-377.

${ }^{56}$ See ibid., 377-378.

57 Other scholars who have tried to read the Fourth Gospel from the same historical perspective as Painter's, have dedicated amply space to the discussion of the formation of these episodes. Kiyoshi TsuchIDO, "Tradition and Redaction in John 12:1-43," New Testament Studies 30(1984): 609-619, is among those scholars who attempted to offer a solution to the narrative sequence in $\mathrm{Jn} 12$. By an analysis based on the method of tradition and redaction criticism, Tsuchido presents some clues to the Evangelist's redaction of his earlier sources and to the historical situation out of which he wrote his Gospel. For a similar position see also, J.F. COAKLEY, “Jesus' Messianic Entry into Jerusalem (John 12:12-19 Par.)," Journal of Theological Studies 46(1995): 461-482.

${ }^{58}$ See J. PAINTER, The Quest for the Messiah, 378-379.

${ }^{59}$ See ibid., 379. 


\section{A FRAME OF REFERENCE}

This broad-brush analysis of Quest provides us with a context for understanding Painter's way of handling the quest and rejection stories in the Fourth Gospel. Painter's proposals have an elegant simplicity as they spot on two important elements that control his exegesis of these stories. Painter offers some fruitful insights into how "quest stories belong to the pre-expulsion situation." 60 During this early period in the history of the Johannine Community, traditional stories concerning the messiahship of Jesus were reformulated by the Fourth Evangelist and inserted in the first edition of the Gospel. Most of these stories are quest stories carrying with them a positive quest for the person of Jesus Christ.

We have also seen how a more comprehensive picture of quest stories in the Fourth Gospel can be grasped by looking at the way Painter relates these stories with the rejection stories. In Quest, Painter furnishes textual examples which indicate that Johannine rejection stories belong to the "post-expulsion" ${ }^{61}$ situation of the Johannine Community. This period in the life of this community, reflected in the second edition of the Gospel, is bound by the tradition of dispute and conflict.

Painter's merit then lies in the way he illustrates how the Fourth Evangelist is responsible for the development of many of the traditions into quest and rejection stories. This frame of reference has a certain attraction and coherence. Chiefly among Painter's merits is the way he claims that quest and rejection stories have a direct social function in the Fourth Gospel. The Fourth Evangelist himself is responsible for shaping these stories in view of the current situation of the Johannine Community. In sum, Painter acknowledges that an examination of the quest and rejection stories in this Gospel can illuminate the situation of the Fourth Evangelist and the Community to whom he was writing. ${ }^{62}$

Painter's Quest has been seminal in this way. Basing his results on this historical model, Painter ranks among the scholars who determined the debate on the genesis of the Johannine tradition in this direction. His observations, in tandem with the works of his predecessors, amply demonstrate that the Johannine tradition bears the marks of alterations and insertions. It is a tradi-

\footnotetext{
${ }^{60}$ Ibid., 7.

61 Ibid.

${ }^{62}$ See ibid.
} 
tion that was interpreted and developed at different stages in line with the history of the Johannine Community. In this way, Quest may be considered as a study that clarifies the result of a movement in reseach grounded on the recognition of a composition history behind the Fourth Gospel related to the history of the Johannine Community. The Johannine Community has rewritten history out of tradition in accordance to its current needs. In Quest, Painter nails this hypothesis and brings some useful insights to it.

On the other hand, attractive and persuasive as much of Painter's arguments are, these seem to be unsatisfactory on a number of counts. Henry Wansbrough attacks Painter's method acknowledging how Painter follows Tannehill's form-critical analysis and supplies a brief description of eight characteristics of the genre. At the same time, Wansbrough states that one of the shortcomings of Quest is that it never rigorously applies these characteristics to the pericope discussed. "As a result, the genre appears so wide as to include almost any story. It becomes perhaps too wide to be useful when it is seen to include the failed quest of Jesus coming to the temple and failing to find what he sought." ${ }^{, 63}$ One must question to what extent one can be certain that Painter's results are not merely wishful thinking in response to a modern interest.

\section{THE VALIDITY OF THE JOHANNINE COMMUNITY HYPOTHESIS}

Adele Reinhartz is among those scholars who voiced her complaint on the recognition that there is a compositional history behind the Fourth Gospel developed in line with the history of the Johannine Community. Reinhartz remarks: "Indeed, because the Fourth Gospel makes no explicit reference to the Johannine Community at all, one might question the possibility of deriving any sociohistorical information whatsoever from this Gospel." ${ }^{64}$ She opens our eyes and helps us to understand that any attempt to reconstruct the history of the Johannine community needs "caution and humility." $65 \mathrm{We}$ must not lose sight of the hypothetical nature of our results. The very exi-

${ }^{63}$ Henry WansBrough, "The Quest for the Messiah," Journal of Jewish Studies 48(1996): 101-102.

${ }^{64}$ Adele Reinhartz, "Woman in the Johannine Community: An Exercise in Historical Investigation," in: A Feminist Companion to John, II, ed. A.-Jill Levine and M. Blickenstaff (Cleveland/OH: The Pilgrim Press, 2003), 14.

65 Ibid., 17. 
stence of a Johannine Community, while it is obvious to Johannine scholars and has taken on a solid reality, is itself hypothetical. ${ }^{66}$ Judith Lieu strikes a similar note in her reflection on the reconstructed community's history. She does not deny the possibility that the Fourth Gospel may reflect the community's history, but at the same time she questions "whether these circumstances can be 'read off' directly from distinctively Johannine passages."

In defining the valuable contribution of sociological insights in the study of the Fourth Gospel, Painter is also very careful to maintain that distinguishing how the story of Jesus overlaps the story of the Johannine Community "remains a task both precarious and controversial." 68 This point is stated from the very beginning of Quest where Painter points out that the approach which reads the story of Jesus as that which bespeaks the history of the Johannine community seems to be "a precarious hypothesis." ${ }^{69}$ Later on, he also adds that "any theory about the nature of the community for which the Gospel was written which will not fit the evidence [...] is bound to be precarious." 70 Painter's presentation of the history of the Johannine community, which reflects the history of the Johannine composition, is weakened by his continual recourse to presenting the hypothetical nature of his historical reconstruction. Quest dedicates an entire section named "Community History - Fact or Fantasy?"71 In a section which speaks about the community and its history, Painter admits that "even in Jn, however, where the reflections are clearest, there are no straightforward data upon which the history of the Johannine community can be based." 72

Painter tries to come to terms with the hypothetical nature of the reconstruction of the history of the Johannine community. Defending his enterprise, he claims that although certainty is relatively small, "this is not an excuse for avoiding reconstruction. All interpretations presuppose some reconstruction, even those based on the naive assumption that the Gospel simply tells the

\footnotetext{
66 See ibid.

${ }^{67}$ Judith M. LIEU, The Second and Third Epistles of John (Edinburgh: T\&T Clark, 1986), 214.

${ }^{68}$ J. PAINTER, The Quest for the Messiah, 24.

${ }^{69}$ Ibid., 7.

${ }^{70}$ Ibid., 80. See also his comment on Brown's discussion of Samaritan inclusion in the Johannine community in ibid., 125.

71 Ibid., 80.

${ }^{72}$ Ibid., 68. See also his comment in ibid., 68, n.104; 70.
} 
story as it happened." ${ }^{73}$ Painter was following here a path that had been cleared by other scholars before him. ${ }^{74}$ In spite the hermeneutical value of these insights which lead us to the social history behind the Fourth Gospel, all these scholarly attempts, including the one by Painter, are frought with difficulty because of the lack of external evidence.

The only external evidence that Painter, following Martyn, can propose is the identification of the "exclusion from the synagogue" of Jn 9:22 with the formulation of the birkat ha-minim, or the so-called "blessings against the heretics," 75 understood as a euphemism for curse. The plausibility of identifying the exclusion from the synagogue passages in the Fourth Gospel with the birkat ha-minim has come under attack. The most telling criticism comes from Reuven Kimelman who points out that there is no such connection between the Johannine expulsion texts and the Benediction against the Heretics. Kimelman forces the need for a reassessment of the conclusions which have been drawn on the basis of such a state of affairs by showing that there are considerable problems in dating this material, establishing its original form, and determining the extent of its influence in different locations. ${ }^{76}$

73 Ibid., 70.

${ }^{74}$ See for example, David RENSERBERG, Johannine Faith and Liberating Community (Philadelphia: Westminister Press, 1988), 15; Martinus C. de BoER, "Narrative Criticism: Historical Criticism, and the Gospel of John," in: The Johannine Writings: A Sheffield Reader (The Biblical Seminar 32), ed. S.E. Porter and C.A. Evans (Sheffield: Sheffield Academic Press, 1995), 103; Wayne A. MeEKs, "The Man from Heaven in Johannine Sectariansim," Journal of Biblical Literature 91(1972): 69.

75 This insight is the crucial element at the center of Martyn's History and Theology in the Fourth Gospel. See especially p.32. The suggestion that this excommunication is to be linked with the insertion into the Eighteen Benedictions of the clause expelling "Heretics" had already been made a century earlier by M. Von ABERLE, "Über den Zweck des Johannesevangelium," Theologische Quartalschrift 42(1861): 37-94. It was suggested once more by Kenneth L. CARroll, "The Fourth Gospel and the Exclusion of Christians," Journal of Biblical Literature 106(1987): 639-652. See also John TownsEnd, "The Gospel of John and the Jews: The Story of a Religious Divorce," in Antisemitism and the Foundation of Christianity, ed. Alan Davies (New York: Paulist Press, 1979), 87; W.D. DAVIES, "Reflections on Aspects of the Jewish Background of the Gospel of John," in: Exploring the Gospel of John, ed. R. Alan Culpepper and C.C. Black (Louisville: Westminister John Knox, 1996): 50-51; Stephen SMALLEY, John: Evangelist and Interpreter (Exeter: Paternoster Press, 1978), 143.

${ }^{76}$ Reuven Kimelman, "Birkat Ha-Minim and the Lack of Evidence for Anti-Christian Jewish Prayer in Late Antiquity," in: Jewish and Christian Self-Definition, II, ed. P. Sanders et al. (Philadelphia: Fortress, 1981), 226-244. For a good scholarly summary of the main arguments against Martyn see, Warren CARTER, John: Storyteller, Interpreter, Evangelist (Peabody: Hendrickson, 2006), 167-168. 
In supporting this view, Wayne Meeks fires the second salvo declaring the birkat ha-minim "a red herring in Johannine research,"77 while Johannes Beutler concludes that "an exclusion of Christians tout court by the Synod of Jamnia cannot be proved."78

Painter acknowledges the attractiveness of the birkat ha-minim since this is "the best known relevant factor external to John that might throw light on this aspect of the Gospel." 79 On the other hand, he makes a stunning effort to distance his arguments from it. In Quest, he insists that it would "be a mistake to become preoccupied with identifying the Johannine situation with the introduction of the birkat ha-minim." For Painter "what is important is the situation of conflict with Formative Judaism whenever and wherever it happened." 80 Despite Painter's efforts to distance himself from the theory of the Eighteenth Benediction, it remains clear that without any external evidence, further clarity on the history of the Johannine Community will be difficult to glean if not with a high dose of speculation and assumption.

\section{THE VALIDITY OF THE EXPULSION THEORY}

In an entire chapter dedicated to questions about the reality of the Johannine Community, Thomas L. Brodie draws attention to the value of the various reconstructions of the history of the Johannine Community as each

77 Wayne A. MeEKs, "Breaking Away: Three New Testament Pictures of Christianity's Separation from the Jewish Communities," in: To See Ourselves as Others See Us: Christians, Jews, 'Others' in Late Antiquity, ed. Jacob Neusner and E.S. Frerichs (Chico/Ca: Scholars Press, 1985), 102; W.A. MeEKs, Man from Heaven in Johannine Sectarianism, 55, n. 40 agrees with Martyn's association of the Birkat ha-minim with the Johannine reference to the expulsion from the synagogue. At the same time, he doubts "whether the decree can be dated precisely." See also Pieter van der HoRst, "The Birkat Ha-Minim in Recent Research," Expository Times 105(1994): 367-368; William Horbury, "The Benediction of the Minim and Early Jewish-Christian Controversy," Journal of Theological Studies 33(1982): 19-61; Adele REINHARTZ, "The Johannine Community and its Jewish Neighbours: A Reappraisal," in: What is John? Literary and Social Reading of the Fourth Gospel, II, ed. Fernando F. Segovia (Atlanta: Scholars Press, 1998), 111-138.

78 Johannes BeUtLER, Judaism and the Jews in the Gospel of John. Subsidia Biblica, 30 (Rome: Biblical Institute Press, 2006), 29.

${ }^{79}$ J. PAINTER, The Quest for the Messiah, 73.

${ }^{80}$ Ibid. See also Painter's defence against the criticism of Kenneth Grayston in his review of the first edition of Quest. See Kenneth Grayston, "Review of Quest," Epworth Review (May 1993), 112. See also J. PAINTER, The Quest for the Messiah, 77. 
apprehend some aspect of the Fourth Gospel, but he also objects to the diversity of views. "Diversity is sufficiently deep that it raises serious questions about the entire undertaking. The most basic question is whether such a community ever existed." 81 Considering the caution that one needs to exercise in any historical reconstruction of the Johannine Community, Brodie seems right to conclude: "The question is not how many bricks in this or that wall are solid but whether there is any solidity to the foundation of the entire house." 82 Martin Hengel raises a more general question regarding such historical reconstruction. "Nowadays we already have too many attempts to reconstruct a 'history of the Johannine community.' They are all doomed to failure, because we know nothing of a real history which even goes back to Palestine, and conjectures about it are idle." 83

Painter's repetitive use of phrases, such as "hypothetical nature," or "complex hypothesis," acknowledge the precarious process of reconstructing the history of the Johannine Community. What purports to be an historical investigation is actually an exercise in creative imagination with very few historical controls. The question regarding the history of the Johannine Community is not remedied by saying that the resulting reconstruction, hypothetical as it is, is nothing like a complete history. What is needed here is a more firmly grounded enterprise on which one may built his results.

Painter's Quest ranks among those works which welcome and adopted Brown's complex theory of composition. Painter hails Brown's basic hypothesis as one which "has become increasingly persuasive," 84 and one that has the power to solve many problems raised by the text of the Gospel as it "has come down to us." 85 Painter is not a voice in the desert. John Ashton's evaluation of redaction that have left their mark in the Fourth Gospel's narrative concludes that despite the variety in the proposals, these reconstructions remain "the right kind of solution." ${ }^{\text {"Q }}$ Quest, in fact, is built on this foundation and it defends the thesis that the Fourth Gospel must have grown hand in hand with the history of the Johannine community. It was the changing situation in the life of the Johannine Christians which led to the

81 Thomas L. BRodie, The Quest for the Origin of John's Gospel: A Source-Oriented Approach (New York/Oxford: Oxford University Press, 1993), 144.

82 Ibid., 21.

${ }^{83}$ Martin Hengel, The Johannine Question (London: SCM Press, 1989), 205, n. 85.

${ }^{84}$ J. PAInTER, The Quest for the Messiah, 2.

${ }^{85}$ Ibid.

${ }^{86}$ J. Ashton, Understanding the Fourth Gospel, 246. 
Christological developments in the Fourth Gospel, and which accounts for the presence of so many aporias. ${ }^{87}$ Quest, thus, associates itself with a large number of Johannine scholars interested in the "diachronic" way of looking at the Fourth Gospel. This approach involves a careful analysis of the various stages through which the text has presumably evolved in order to recover the original historical situation.

Painter adopts this approach to the Fourth Gospel, although he is ready to claim that his attempt is not "to isolate and reconstruct the source(s) in detail." 88 He probably rightly states that "the compositional methods of the evangelist have made this too uncertain to be practicable." 89 The reason he brings is in line with previous other arguments, namely, "clues that seem to indicate the use of sources and a process of redaction have led to no certain conclusions." 90

The impossibility to work out word-for-word reconstructions, however, did not revoke Painter's task to trace the historical circumstances in which the Fourth Gospel was written. In Quest, he articulates a clear methodology which underlines his mode of reading the Fourth Gospel. His application of the Historical Critical Method as an attempt to unfold the genesis of the Fourth Gospel's tradition has proved to be quite fruitful. It gives grounds for a further consideration that the Fourth Gospel is not an instant writing, but one that was edited over a period of years according to the changing situation of the Johannine Christians. Yet, concerned above all to establish the original historical context of the Fourth Gospel, Painter seems to be more interested in reading between the lines than in reading the lines themselves!

\section{COMPETING PARADIGMS}

The way in which Painter determines his research no longer has the explanatory power it once had as the methods and the approaches of scholars who have treated this matter more recently vary considerably. The Historical Critical way of reading the Fourth Gospel has come under increasingly attack from alternative voices emerging in the 1970 s and early 1980 s. ${ }^{91}$ Within

\footnotetext{
87 J. PAINTER, The Quest for the Messiah, 423.

88 Ibid., 28.

89 Ibid.

90 Ibid., 61.

91 For an account of the rise of these competing paradigms see, Fernando F. SEGOVIA,
} 
this "Copernican turn in biblical studies," 92 the experience of reading the text, that is, how the narrative text affects its readers, is more important than understanding the history of its composition. The result of this holistic approach reveals the Fourth Evangelist to be a masterful storyteller in full command of his material. New approaches and methods, then, propose integrated interpretations that establish overarching themes that hold these seemingly literary incoherencies together. ${ }^{93}$

This is why Painter's understanding of the meaning and use of zeteo in his analysis of quest stories has little to say for today's readers. Painter has deposit the Fourth Gospel in the distant past, as if it had never forced our present. In order to grasp the meaning and function of zeteo in the Fourth Gospel, we should rather attempt to read this Gospel as it stands. This way of reading the Gospel reveals the narrative skills and the theological vision of the Fourth Gospel by simply asking what do we see in this Gospel when we turn from source and redaction reading to analyses of its final form. By doing so, the investigation of the meaning of zeteo in the Fourth Gospel will guide the readers to demonstrate that this Gospel is a living word for believers who creatively address new questions to the text.

\section{BIBLIOGRAPHY}

Ashton John, Understanding the Fourth Gospel (Oxford: Clarendon Press, 1993).

BARRETT C.K., The Gospel according to St. John: An Introduction with Commentary and Notes on the Greek Text, ed. 2 (London: SPCK 1978).

BEUTLER Johannes, Judaism and the Jews in the Gospel of John. Subsidia Biblica 30 (Rome: Biblical Institute Press, 2006).

Bretschnieder K.G., Probabilia de evangelii et epistularum Joannis, apostoli, indole et origine (Leipzig, 1820).

\footnotetext{
“"And They Began to Speak in Other Tongues:' Competing Paradigms in Contemporary Biblical Criticism," in: Reading From This Place, I: Social Location and Biblical Interpretation in the United States, ed. Fernando F. Segovia and Mary Ann Tolbert (Minneapolis: Fortress Press, 1995), 1-31.

92 W.H. KelBer, "Metaphysics and Marginality in John," in: What is John? Readers and Readings of the Fourth Gospel. Society of Biblical Literature Symposium Series 3, vol. 1, ed. Fernando F. Segovia (Atlanta: Scholars, 1996), 142.

${ }^{93}$ A detailed discussion on this subject is provided by Jeffrey L. STALEY, The Print's First Kiss: A Rhetorical Investigation of the Implied Reader in the Fourth Gospel. Society of Biblical Literature Dissertation Series, 82 (Atlanta: Scholars, 1988).
} 
BRodiE Thomas L., The Quest for the Origin of John's Gospel: A Source-Oriented Approach (New York/Oxford: Oxford University Press, 1993).

Brown Raymond E., The Gospel according to John. Anchor Bible 29, 29A (Garden City/New York: Doubleday, 1966-1970).

Brown Raymond E., The Community of the Beloved Disciple: The Life, Loves and Hates of an Individual Church in New Testament Times (New York/London: Paulist, 1979).

Bultmann Rudolf, The Gospel of John, trans. G.R. Beasley-Murray (Oxford: Blackwell, 1971).

CARroll Kenneth L., "The Fourth Gospel and the Exclusion of Christians," Journal of Biblical Literature 106(1987): 639-652.

CARTER Warren, John: Storyteller, Interpreter, Evangelist (Peabody: Hendrickson, 2006).

COAKLEY J.F., "Jesus' Messianic Entry into Jerusalem (John 12:12-19 Par.)," Journal of Theological Studies 46(1995): 461-482.

DAVIES W.D., "Reflections on Aspects of the Jewish Background of the Gospel of John," in Exploring the Gospel of John, ed. R. Alan Culpepper and C.C. Black (Louisville: Westminister John Knox, 1996): 43-64.

DE BoER Martinus C., "Narrative Criticism: Historical Criticism, and the Gospel of John," in The Johannine Writings: A Sheffield Reader (The Biblical Seminar 32), ed. S.E. Porter and C.A. Evans (Sheffield: Sheffield Academic Press, 1995), 95-108.

GRAYSTON Kenneth, "Review of Quest," Epworth Review (May 1993): 112.

HeNGEL Martin, The Johannine Question (London: SCM Press, 1989).

Horbury William, "The Benediction of the Minim and Early Jewish-Christian Controversy," Journal of Theological Studies 33(1982): 19-61.

KeLber W.H., "Metaphysics and Marginality in John," in What is John? Readers and Readings of the Fourth Gospel. Society of Biblical Literature Symposium Series 3, vol. 1, ed. Fernando F. Segovia (Atlanta: Scholars, 1996), 129-154.

KIMELMAN Reuven, "Birkat Ha-Minim and the Lack of Evidence for Anti-Christian Jewish Prayer in Late Antiquity," in Jewish and Christian Self-Definition, II, ed. Ed P. Sanders et al. (Philadelphia: Fortress, 1981), 226-244.

LIEU Judith M., The Second and Third Epistles of John (Edinburgh: T\&T Clark, 1986).

LIEU Judith M., "The Quest for the Messiah," Expository Times 103(1992): 345.

MARTYN J. Louis., "Glimpses into the History of the Johannine Community," in The Gospel of John in Christian History: Essays for Interpreters (New York: Paulist, 1978), 90-121.

MARTYN J. Louis, History and Theology in the Fourth Gospel, ed. 2 (Nashville: Abingdon Press, 1979).

MARTYN J. Louis, „Source Criticism and Religionsgeschichte in the Fourth Gospel,” in The Interpretation of John, ed. John Ashton, ed. 2 (Edinburgh: T\&T Clark, 1997), 121-146.

MeEKs Wayne A., "The Man from Heaven in Johannine Sectariansim," Journal of Biblical Literature 91(1972): 44-72.

MeEKs Wayne A., "Breaking Away: Three New Testament Pictures of Christianity's Separation from the Jewish Communities," in To See Ourselves as Others See Us: Christians, Jews, 'Others' in Late Antiquity, ed. J. Neusner and E.S. Frerichs (Chico/Ca: Scholars Press, 1985), 93-115.

NeufELD Dietmar, ”The Quest for the Messiah," Catholic Biblical Quarterly 57(1995): 604605.

PAINTER John, The Quest for the Messiah: The History, Literature and Theology of the Johannine Community, ed. 2 (Edinburgh: T\&T Clark, 1993). 
ReINHARTZ Adele, "The Johannine Community and its Jewish Neighbours: A Reappraisal," in What is John? Literary and Social Reading of the Fourth Gospel, II, ed. Fernando F. Segovia (Atlanta: Scholars Press, 1998), 111-138.

ReInHARTZ Adele, "Woman in the Johannine Community: An Exercise in Historical Investigation," in A Feminist Companion to John, II, ed. A.-Jill Levine and M. Blickenstaff (Cleveland/OH: The Pilgrim Press, 2003), 14-32.

RENSERBERG David, Johannine Faith and Liberating Community (Philadelphia: Westminister Press, 1988).

SEgovia Fernando F., „'And They Began to Speak in Other Tongues:' Competing Paradigms in Contemporary Biblical Criticism," in Reading From This Place, I: Social Location and Biblical Interpretation in the United States, ed. Fernando F. Segovia and Mary Ann Tolbert (Minneapolis: Fortress Press, 1995), 1-31.

SMALley Stephen, John: Evangelist and Interpreter (Exeter: Paternoster Press, 1978).

Staley Jeffrey L., The Print's First Kiss: A Rhetorical Investigation of the Implied Reader in the Fourth Gospel. Society of Biblical Literature Dissertation Series 82 (Atlanta: Scholars, 1988).

TOWnSEND John, "The Gospel of John and the Jews: The Story of a Religious Divorce," in Antisemitism and the Foundation of Christianity, ed. Alan Davies (New York: Paulist Press, 1979), 79-97.

TsuCHIDO Kiyoshi, "Tradition and Redaction in John 12:1-43," New Testament Studies 30(1984): 609-619.

VAN DER HORST Pieter, "The Birkat Ha-Minim in Recent Research," Expository Times 105(1994): 367-368.

VON ABERLE M., „Über den Zweck des Johannesevangelium,” Theologische Quartalschrift 42(1861): 37-94.

Wansbrough Henry, „The Quest for the Messiah,” Journal of Jewish Studies 48(1996): 101102.

\author{
UŻYCIE ZETEO W CZWARTEJ EWANGELII: \\ DEBATA Z THE QUEST FOR THE MESSIAH JOHNA PAINTERA
}

\title{
STRESZCZENIE
}

Artykuł jest forma debaty z monografia Johna Paintera The Quest for the Messiah: The History, Literature and Theology of the Johannine Community obszernie podejmująca temat zeteo (poszukiwania) w Ewangelii Jana. W publikacji tej Painter doszedł do wielu cennych rezultatów w próbach ustalenia znaczenia zeteo w Ewangelii Janowej, analizując przedstawione historie poszukiwań i odrzucenia. Artykuł przedstawia, w jakim stopniu Painter zrozumiał historyczne pochodzenie zeteo w stosunku do Sitz im Leben Wspólnoty Janowej. Opisuje także niektóre z możliwych kierunków rozwoju myśli Paintera i zwraca uwagę na niektóre nurty ostatnich badań nad Ewangelią św. Jana.

Słowa kluczowe: szukanie; metoda historyczno-krytyczna; źródła; Wspólnota Janowa; poszukiwanie; odrzucenie. 